\title{
Educational Transition Amid COVID-19 Outbreak in Africa: Challenges and Opportunities for Medical Education
}

\author{
Oluwatosin Imoleayo Oyeniran ${ }^{1 *}$, Abayomi Oyeyemi Ajagbe' ${ }^{2}$, Oluwanisola Akanji Onigbinde², Terkuma Chia ${ }^{2}$, \\ Akintunde Tosin Yinka ${ }^{3}$ \\ 'Department of Physiology, Faculty of Basic Medical Sciences, College of Health Sciences, Nile University of Nigeria, Abuja \\ ${ }^{2}$ Department of Anatomy, Faculty of Basic Medical Sciences, College of Health Sciences, Nile University of Nigeria, Abuja \\ ${ }^{3}$ Department of Sociology, School of Public Administration, Hohai University, No 8, Focehnxi Lu, Jiangning Campus, \\ Jiangning District, Nanjing, PR China 211100
}

\section{*Correspondence to Oluwatosin Imoleayo Oyeniran, Department of Physiology, Faculty of Basic Medical Sciences, College of Health Sciences, Nile University of Nigeria, Abuja, Nigeria. Tel: +2348182091384; Email tosinoyeniran1@gmail.com \\ Received Ausuts 08, 2021 Accepted August 25, 2021 Published online September 30,2021

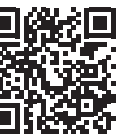

Please cite this article as follows: Oyeniran OI, Ajagbe AO, Onigbinde OA, Chia T, Yinka AT. Educational transition amid covid-19 outbreak in africa: challenges and opportunities for medical education. Int J Basic Sci Med. 2021;6(3):7679. doi:10.34172/ ijbms.2021.14.

\begin{abstract}
The coronavirus disease 2019 (COVID-19) pandemic has resulted in numerous alterations in today's world. These include the temporary closure of educational institutions as part of recommended measures by the World Health Organization (WHO) to mitigate its spread, thus causing over one million students to stay at home globally. Generally, education has witnessed a transition from traditional face-to-face learning to virtual and online learning. This unexpected shift has presented a series of challenges especially within the African region where before now the educational sector is known to be deficient in funding and infrastructure. The cardinal position of medical education in providing healthcare workers can be enhanced and advanced by subduing these challenges and maximizing the available opportunities for its immediate and future needs. The aim of this paper is to highlight the steps Africa needs to take to improve medical education and invent methods for quality teaching and learning in medical education. Keywords: Africa, COVID-19, Educational transition, Medical education, Online learning, Pandemic
\end{abstract}

\section{Introduction}

The deadly novel coronavirus disease (COVID-19) outbreak was declared as a Public Health Emergency of International Concern on 30 January 2020 by World Health Organization (WHO), ${ }^{1}$ after its emergence at Wuhan city, China. The global spread of the pandemic has posed adverse effects on the African continent, who currently have over 1802351 confirmed cases and 43421 deaths as of November $3,2020 .^{2}$ The ban of activities in various sectors, restriction of movements, and the prohibition of public gatherings among other measures are the aftermath of the daily surge in COVID-19 cases, to curtail its further spread following the WHO recommendations and standards. ${ }^{3-10}$ The educational sector was among the seriously affected sectors, as most institutions of learning have ceased academic activities across the globe since early March 2020, and over 850 million learners were lockdown at home. ${ }^{10,11}$ Globally, transitioning to emergency online teaching and learning has been espoused after schools' closure pro-tem. African countries were left with no better option than to join their counterparts around the globe if teaching and learning must continue..$^{10,12}$

As stated by UNESCO, sub-Saharan Africa has the high-rise rates of education exclusion in the world. More than one-fifth of children between the age range of 6 to 11 and one-third of youth between the ages of 12 and 14 are out of school. Close to $60 \%$ of youths between the ages of 15 and 17 are also not in school. ${ }^{13}$ The UNESCO estimated that only 1 in 250 individuals in sub-Saharan Africa have access to the internet as against the global average of 1 in $15 .^{14}$

(C) 2021 The Author(s); Published by Zabol University of Medical Sciences. This is an open-access article distributed under the terms of the Creative Commons Attribution License (http://creativecommons.org/licenses/by/4.0), which permits unrestricted use, distribution, and reproduction in any medium, provided the original work is properly cited. 
Internet connectivity is an imperative element for the growth of any nation which assists to gain necessary intelligence in the areas of education, health care, business and politics for human development. Globally, access to the internet is not equally available. While some regions have unwavering access, many developing regions are deficient of even basic connectivity. ${ }^{15}$ As stated by global statistic in 2011, juxtaposing between developed countries and developing countries' access to the internet showed that a percentage higher than $73 \%$ and $26 \%$ of individuals had internet connection respectively. Some countries in Sub-Saharan Africa like Liberia, Niger and the Democratic Republic of Congo are greatly lagging with access rate less than $1 \%$ of the population. ${ }^{15}$ This aim of this paper is to highlight the steps Africa needs to take to improve medical education and invent methods for quality teaching and learning in medical education.

\section{History of COVID-19 in Africa}

COVID-19 was first discovered in Wuhan city of China, and later spread to most countries such as the United States of America, Spain, Italy, Belgium, Canada, Brazil, and the continent of Africa. ${ }^{16}$ The first case in Africa was discovered in Egypt on February 14, 2020, and shortly followed by Nigeria on February 27, 2020. According to the Africa CDC, about 1802351 cases, comprising of 43421 deaths and 1475897 recoveries from the 54 African countries have been reported on November 3, 2020. ${ }^{2}$ The origin of most of these recognized cases in Africa are from Europe and the United States of America. ${ }^{16}$

\section{Education Transition in Africa Amid COVID-19 Pandemic}

Since the emergence of COVID-19 pandemic, educational activities in institutions are pro-tem ceased in response to restrictions orders on social gathering, as part of the measure by the World Health Organization to curtail its spread. ${ }^{17,18}$ This has consequently made millions of students around the globe to stay at home. ${ }^{19}$ Besides, many institutions of learning have shifted to emergency online teaching and learning. ${ }^{20}$ This form of online learning where students acquire knowledge through "invisible classrooms" is gradually evolving globally. ${ }^{21}$ Zoom meeting, Google classroom, Adobe Captivate amongst others have been the mode of promulgating information electronically and positive outcomes have been recorded. ${ }^{20,22,23}$

\section{E-Learning System and Medical Education in Africa: Challenges and Opportunities}

Policies have been put in place by some African governments which have assisted in developing digital learning. For instance, Rwanda in partnership with Microsoft has proposed to modify all its classrooms to wired "smart" classrooms by $2020 .{ }^{24}$ According to the annual report, Africa Virtual and E-University had trained about 63000 students across Africa by 2015 and set up the largest network of open distance and e-learning institutions in sub-Saharan Africa. ${ }^{24}$ Other online universities have also been established in Africa such as; the UNICAF University, the Virtual University of Uganda, and the Virtual University of Senegal. More so, distance learning centres have been established which includes; Wits Plus at the University of the Witwatersrand (South Africa), the Distance Learning Centre of Ahmadu Bello University (Nigeria), or Kenyatta University's Digital School of Virtual and Open Learning (Kenya). ${ }^{24}$

With the inception of online learning in Africa, one of the opportunities it has presented to medical education is virtual dissection, which is a prolific platform in medical anatomy education. This entails interconnection with 3D reconstructions and studies have shown the educational advantages of introducing 3D technologies into the teaching of human anatomy. ${ }^{25}$ Typical examples of novel 3D anatomy models include; Biodigital Human, Primal pictures, Elsevier, 3D4medical, Zygote Body which has been espoused by developed countries. ${ }^{26}$

\section{Challenges}

One of the channels to the growth of any nation is the access to information which help human development in education, economy, healthcare and politics. Internet connections has indeed speed up these achievements. Access to the internet globally has been unequally distributed with many developing countries lacking basic connectivity. ${ }^{15}$

There exist a lot of challenges with the implementation, connections and smooth running of ICT in most African countries far before the emergence of COVID-19. Electronic resources for ICT appear to be inaccessible to most African countries due to the lack of technological support structures to receive and share effectively. Furthermore, the challenges at higher institutional level revolves around regulation of the telecommunications and IT policies. ${ }^{15}$

The rate of internet penetration in sub-Saharan Africa is greatly poor juxtaposed to other developing countries with less than $1 \%$ penetration rate in countries like Liberia, Niger, the Democratic Republic of Congo and Ethiopia. This will cause a hiccup on the rate of transition to online learning during this pandemic in those developing countries. Some of the reasons for straggling in internet penetration of developing countries are inadequate supporting sub-structures like electricity, obsolete regulatory frameworks and cost implication. ${ }^{15}$

In African medical education, the use of cadaveric dissection for anatomy teaching continues to be laced with challenges ${ }^{27,28}$ and have become a major concern for educators in the face of the current COVID-19 pandemic. 
These include the fear that cadavers might be infectious if not properly preserved, and difficulties in obtaining unclaimed bodies (the primary source of cadavers in most medical school), that are medically certified to be COVID-19 free.

\section{Opportunities}

Learning and teaching in medical education has gradually metamorphosed from the use of conventional and traditional cookbook methods to multimedia, computerbased and web-based learning. The COVID-19 outbreak has presented a fascinating window of opportunity for medical schools in Africa to launch into the use of virtual software for teaching.

For instance, anatomy education is experiencing a paradigm shift from the use of cadavers and prosected specimens to utilizing plastinated models, multimedia, computer or web-based learning, and other virtual anatomy software. ${ }^{29}$ Virtual dissection, such as the Anatomage table is now commonly used to teach anatomy. It presents imaging of $3 \mathrm{D}$ anatomy and communicative imaginations such as an embalmed cadaver. ${ }^{29}$ Its course of action involves a virtual dissection table loaded with medical imaging datasets, which can be watched in $3 \mathrm{D}$ while the students maneuver the images via digital tools to perform dissection. ${ }^{25}$ Male and female complete body anatomy (head to toe) with details such as minute nerves and blood vessels can be viewed at better resolutions. ${ }^{29}$ Many virtual dissection tables help in learning via juxtaposing two clinical presentations or medical cases, tumor growth examination, and review of pre- and postsurgery cases.

Physiology education on the other hand, is constantly evolving as seen in the use of state-of-the-art computer or web-based data acquisition systems and virtual physiology software to demonstrate physiological experiments and bodily processes..$^{30,31}$ These innovations have provided a great opportunity for online learning in medical education in Africa.

\section{Conclusion}

The closure of schools globally should not be a source of major concern, and academic activities would not have been completely withheld if certain measures are put in place even in the poorest developing countries. The following are the prompt urgent actions that can be adopted during the current COVID-19 pandemic to ensure the continuation of teaching and learning;

1. Establishment of learning durability programs: These include broadcast through the radio and television with provision of resources such as radios, study guides and equipment to the less privileged. Virtual telephone teaching can also be provided through tollfree tutoring. ${ }^{32}$

2. Monitoring learning at different grade levels: Where online learning through the internet is adopted, it will be imperative to monitor the students' academic progress in the face of poor internet connection and social media distractions. This will help to know those being reached so that proper intervention can be applied systematically in cogent areas. ${ }^{32}$

3. Understanding its effect on the education of the Poor: Presumably, there is likely to see a similar drop in income during the COVID-19 pandemic, as observed in the fall of annual household income in Sierra Leone from US\$336 to US\$131 during the Ebola pandemic. This will make internet subscription for education purpose to be difficult. Therefore, urgent interventions for the most vulnerable such as conditional cash transfers will help them to continue learning. ${ }^{32}$

Ethical Approval

Not applicable.

\section{Competing Interest}

The authors declare that there is no conflict of interest.

\section{Authors' Contributions}

OIO formulated the study. AOA, OAO, TC, ATY carried out the investigation, obtained, sorted, analyzed, and presented the data. All authors drafted, revised, and approved the initial and final article, and are liable for the manuscript.

\section{References}

1. World Health Organization (WHO). COVID-19 Public Health Emergency of International Concern (PHEIC) Global research and innovation forum. https://www.who.int/publications/m/ item/covid-19-public-health-emergency-of-internationalconcern-(pheic)-global-research-and-innovation-forum. Accessed October 25, 2020.

2. Africa CDC. Coronavirus disease 2019 (COVID-19). Available from: https://africacdc.org/covid-19/. Accessed November 3, 2020.

3. Chia TI, Oyeniran OI. Human health versus human rights: an emerging ethical dilemma arising from coronavirus disease pandemic. Ethics Med Public Health. 2020;14:100511. doi:10.1016/j.jemep.2020.100511

4. Oyeniran OI, Chia TI. Novel coronavirus disease 2019 (COVID-19) outbreak in Nigeria: how effective are government interventions? Ethics Med Public Health. 2020;14:100515. doi:10.1016/j.jemep.2020.100515

5. Chia TI, Oyeniran OI. Will Africa experience a spike in COVID-19 cases? Asian Pac J Trop Med. 2020;13(7):285-287. doi:10.4103/1995-7645.282560

6. Oyeniran OI, Chia TI. Fighting the coronavirus disease (COVID-19) pandemic: employing lessons from the Ebola virus disease response. Ethics Med Public Health. 2020;15:100558. doi:10.1016/j.jemep.2020.100558

7. Oraebosi Ml, Chia T, Oyeniran Ol. Preparing the next generation of African Healthcare Workers and Scientists: Lessons from Corona Virus Pandemic. Ethics Med Public Health. 2020;14:100535. doi:10.1016/j.jemep.2020.100535

8. Oyeniran OI, Chia TI, Onigbinde O, Ajagbe A. Avoiding an imminent catastrophe from COVID-19 pandemic in Africa: the need to urgently prohibit mass gatherings. Cumhur Med J. 2020;42(2):203-207. doi:10.7197/cmj.vi.755576 
9. Oyeniran OI, Chia TI, Oraebosi MI. Combating COVID-19 pandemic in Africa: an urgent call to scale up laboratory testing capacities. Ethics Med Public Health. 2020;15:100552. doi:10.1016/j.jemep.2020.100552

10. Mulenga EM, Marbán JM. Is COVID-19 the gateway for digital learning in mathematics education? Contemp Educ Technol. 2020;12(2):ep269. doi:10.30935/cedtech/7949

11. UNESCO. Half of world's student population not attending school: UNESCO launches global coalition to accelerate deployment of remote learning solutions. Available from: https://en.unesco.org/news/half-worlds-student-populationnot-attending-school-unescolaunches-global-coalitionaccelerate. Accessed October 27, 2020.

12. Oyeniran OI. Impacts of Novel COVID-19 Pandemic on Furtherance of Medical Education: Challenges and Possible Prospects. Ulutas Med J. 2021;7(1):4-7.

13. UNESCO. Education in Africa. Available from: http://uis unesco.org/en/topic/education-africa. Accessed October 28 , 2020.

14. Asunka S. Online learning in higher education in sub-Saharan Africa: Ghanaian University students' experiences and perceptions. International Review of Research in Open and Distributed Learning. 2008;9(3):1-23. doi:10.19173/irrodl. v9i3.586

15. Pejovic V, Johnson DL, Zheleva M, Belding E, Parks L, van Stam G. Broadband adoption| the bandwidth divide: obstacles to efficient broadband adoption in rural sub-Saharan Africa. Int J Commun. 2012;6:2467-2491

16. Lone SA, Ahmad A. COVID-19 pandemic - an African perspective. Emerg Microbes Infect. 2020;9(1):1300-1308. do i:10.1080/22221751.2020.1775132

17. Chia TI, Oyeniran OI. Human health versus human rights: an emerging ethical dilemma arising from coronavirus disease pandemic. Ethics Med Public Health. 2020;14:100511. doi:10.1016/j.jemep.2020.100511

18. Nigeria Center for Disease Control (NCDC). Self-Isolation \& Quarantine Guide. Available from: https://covid19.ncdc.gov. ng/media/archives/SelfIsolation_QuarantineGuide.pdf.pdf. Accessed October 29, 2020.

19. UNESCO. Half of world's student population not attending school: UNESCO launches global coalition to accelerate deployment of remote learning solutions. Available from: https://en.unesco.org/news/half-worlds-student-populationnot-attending-school-unescolaunches-global-coalitionaccelerate. Accessed October 29, 2020.

20. Adeoye IA, Adanikin AF, Adanikin A. COVID-19 and e-learning: Nigeria tertiary education system experience. Int J Res Innov Appl Sci. 2020;5(5):28-31.

21. Tham CM, Werner JM. Designing and evaluating e-learning in higher education: a review and recommendations. J Leadersh Organ Stud. 2005;11(2):15-25. doi:10.1177/107179190501100203

22. Cappel JJ, Hayen RL. Evaluating e-learning: a case study. J Comput Inf Syst. 2004;44(4):49-56. doi:10.1080/08874417. 2004.11647595

23. Dalton W, Turner B. Best online learning platforms of 2020: LMS and VLE for education. Available from: https://www. techradar.com/best/best-online-learning-platforms. Accessed October 29, 2020.

24. World Education News+ Reviews (Educating the Masses: The Rise of online Education in Sub-Saharan Africa and South Asia. Available from: https://wenr.wes.org/2018/08/ educating-the-masses-the-rise-of-online-education. Accessed October 30, 2020.

25. Darras KE, Spouge R, Hatala R, et al. Integrated virtual and cadaveric dissection laboratories enhance first year medica students' anatomy experience: a pilot study. BMC Med Educ. 2019;19(1):366. doi:10.1186/s12909-019-1806-5

26. Zilverschoon M, Vincken $\mathrm{KL}$, Bleys RL. The virtual dissecting room: creating highly detailed anatomy models for educational purposes. J Biomed Inform. 2017;65:58-75. doi:10.1016/j.jbi.2016.11.005

27. Chia TI, Oyeniran OI. Ethical considerations in the use of unclaimed bodies for anatomical dissection: a call for action. Ulutas Med J. 2020;6(1):5-8. doi:10.5455/ umj.20201229101758

28. Chia TI, Oyeniran OI, Ajagbe AO, Onigbinde OA, Oraebosi MI. The symptoms and stress experienced by medical students in anatomy dissection halls. J Taibah Univ Med Sci. 2020;15(1):8-13. doi:10.1016/j.jtumed.2020.01.001

29. Periya SN, Moro C. Applied learning of anatomy and physiology: virtual dissectiontables within medical and health sciences education. Bangkok Med J. 2019;15(1):121. doi:10.31524/bkkmedj.2019.02.021

30. FitzPatrick KA. An investigative laboratory course in human physiology using computer technology and collaborative writing. Adv Physiol Educ. 2004;28(1-4):112-119. doi:10.1152/advan.00007.2004

31. Lewis MJ. Computer-assisted learning for teaching anatomy and physiology in subjects allied to medicine. Med Teach. 2003;25(2):204-207. doi:10.1080/0000000000000000000a

32. Global Partnership for Education. Mitigating COVID-19 impacts and getting education systems up and running again: Lessons from Sierra Leone. Available from: https://www. globalpartnership.org/blog/mitigating-covid-19-impacts-andgetting-education-systems-and-running-again-lessons-sierra. Accessed October 31, 2020. 